\title{
Organic systems in the growth and essential-oil production of the yarrow $^{1}$
}

\author{
Sistemas orgânicos no crescimento e produção de óleo essencial em mil-folhas
}

\author{
Elza Oliveira Ferraz ${ }^{2}$, Suzan Kelly Vilela Bertolucci ${ }^{3 *}$, José Eduardo Brasil Pereira Pinto ${ }^{3}$, Andreísa Flores \\ Braga $^{4}$ e Andressa Giovannini Costa ${ }^{4}$
}

\begin{abstract}
Fertilization of the soil with organic fertilizers has been gaining importance within the concept of sustainable crop production. This study aimed evaluates the effects of dosages of cattle and poultry manure on Achillea millefolium L. as regards the vegetative growth and the content and chemical composition of its essential oil. For the cattle manure fertilization the dosages evaluated were: 1) soil with no fertilizer; 2) soil + $3.0 \mathrm{~kg} \mathrm{~m}^{-2}$; 3) soil $+6.0 \mathrm{~kg} \mathrm{~m}^{-2} ; 4$ ) soil $+9.0 \mathrm{~kg} \mathrm{~m}^{-2}$ and 5) soil $+12.0 \mathrm{~kg} \mathrm{~m}^{-2}$. For fertilization with poultry manure: 1) soil without fertilizer; 2) soil $+1.5 \mathrm{~kg} \mathrm{~m}^{-2} ; 3$ ) soil $+3.0 \mathrm{~kg} \mathrm{~m}^{-2}$; 4) soil $+4.5 \mathrm{~kg} \mathrm{~m}^{-2}$ and 5) soil $+6.0 \mathrm{~kg} \mathrm{~m}^{-2}$. The experimental design was completely randomized, with four replications per treatment and four plants per experimental plot. Harvesting took place at 110 days and the following variables were measured: shoot and root dry biomass; root to shoot ratio and the content, yield and chemical composition of the essential oil. Data were submitted to variance and regression analyses. A. millefolium has more intense response in fertilization with poultry manure than to that of cattle, where the dosage of $6 \mathrm{~kg} \mathrm{~m}^{-2}$ presented the greatest shoot dry weight and highest yield of essential oil. Without regard to fertilization, the essential oil of $A$. millefolium consists mainly of chamazulene, with the applied treatments not significantly interfering in the oil chemical composition and content.
\end{abstract}

Key words: Achillea millefolium L.. Essential oil. Organic fertilizer. Soil fertily. Biomass.

RESUMO - A fertilização dos solos com adubos orgânicos tem adquirido importância do ponto de vista da concepção de produção vegetal sustentável. Foi objetivo deste trabalho avaliar os efeitos de dosagens de esterco bovino e avícola em Achillea millefolium L. no crescimento vegetativo, teor e composição química do óleo essencial. Na fertilização com o esterco bovino avaliaram-se as doses: 1) Solo sem adubação; 2) solo + 3,0 $\mathrm{kg} \mathrm{m}^{-2}$; 3) solo + 6,0 $\mathrm{kg} \mathrm{m}^{-2}$; 4) solo + 9,0 $\mathrm{kg} \mathrm{m}^{-2}$; 5) solo + 12,0 kg m². $\mathrm{Na}$ adubação com esterco avícola: 1) solo sem adubação; 2) solo + 1,5 $\mathrm{kg} \mathrm{m}^{-2}$; 3) solo + 3,0 $\mathrm{kg} \mathrm{m}^{-2}$; 4) solo + 4,5 $\mathrm{kg} \mathrm{m}^{-2} \mathrm{e} \mathrm{5)}$ solo $+6,0 \mathrm{~kg} \mathrm{~m}^{-2}$. O delineamento experimental utilizado foi o inteiramente casualizado com quatro repetições por tratamento e quatro plantas por parcela experimental. A colheita ocorreu aos 110 dias e avaliaram-se as biomassas secas da parte aérea e raiz, razão raiz/parte aérea, teor, rendimento e composição química do óleo essencial. Os dados foram submetidos à análise de variância e de regressão. A. millefolium responde com maior intensidade a adubação com esterco avícola que com a bovina, onde a dose de $6 \mathrm{~kg} \mathrm{~m}^{-2}$ apresentou o maior acúmulo de biomassa seca da parte aérea e maior rendimento de óleo essencial. Independente da adubação das plantas, o óleo essencial da A. millefolium é constituído majoritariamente por camazuleno e os tratamentos aplicados não interferiram expressivamente na composição e teor dos constituintes químicos do óleo.

Palavras-chave: Achillea millefollium L.. Óleos essenciais. Fertilizante orgânicos. Fertilidade do solo. Biomassa vegetal.

\footnotetext{
*Autor para correspondência

${ }^{1}$ Recebido para publicação em 27/04/2012; aprovado em 07/10/2013

Parte da Dissertação de Mestrado do primeiro autor apresentada ao Programa de Pós-Graduação em Agronomia/Fitotecnia do Departamento de Agricultura da Universidade Federal de Lavras/UFLA

${ }^{2}$ Programa de Pós-Graduação em Agronomia com área de concentração em Fitotecnia, Universidade Federal de Lavras/UFLA, Lavras-MG, Brasil, 37.200-000, elza.o.ferraz@hotmail.com

${ }_{3}^{3}$ Departamento de Agricultura, Setor de Plantas Medicinais/UFLA, Lavras-MG, Brasil, 37.200-000, suzan@ dag.ufla.br, jeduardo@ dag.ufla.br

${ }^{4}$ Departamento de Agricultura da Universidade Federal de Lavras/UFLA, Lavras-MG, Brasil, 37.200-000, andreisaflores@hotmail.com, dessagc@yahoo.com.br
} 


\section{INTRODUCTION}

Organic production systems have seen an exponential growth in popularity in recent years. However protocols for horticultural organic-production systems are still in their infancy (SURRAGE et al., 2010). In the production of medicinal and aromatic plants, these are becoming almost mandatory, since nowadays most large companies producing herbal pharmaceuticals, as well as those marketing herbs, give preference to plant materials which come from certified biodynamic or organic crops (SCHIPPMANN et al., 2002).

Achillea millefolium L. (Asteraceae), popularly known as yarrow, is one of the species listed on the National Register of Medicinal Plants of Interest to the Brazilian Health Service (RENISUS), being species which are widely used by the Brazilian population, and for which there is already evidence as to their appropriate application, however further studies are needed to determine growing conditions and agricultural production, safety, efficacy and definitions of the most suitable pharmaceutical form (BRAZIL, 2009). A. millefolium has been used in folk medicine against various disorders, including skin inflammations, spasmodic, gastrointestinal and hepatobiliary disorders (BENEDEK; KOPP, 2007). Phytochemical studies of Achillea millefolium have identified several components, including essential oils, sesquiterpenes and phenolic compounds such as flavonoids and fatty phenilcarbonics (BENEDEK; KOPP; MELZIG, 2007). The species is native to temperate regions and has adapted well to the climatic conditions in Brazil, however studies aimed at plant productivity and the levels and chemical composition of the essential oil are just beginning (LORENZI; MATOS, 2002).

Several aromatic species have been studied in order to assess the effects of organic fertilization on plant productivity and the synthesis of their volatile constituents, such as Plectranthus neochilus Schltr. (ROSAL et al., 2011), Aloysia triphylla Britton. (BRANT et al., 2010), Origanum vulgare L. (CORRÊA et al., 2010), Ocimum gratissimum L. (BIASI et al., 2009), Salvia fruticosa Mill. (KAPLAN et al., 2009), Melissa officinallis L. (SANTOS et al., 2009), Chamomila recutita L. (AMARAL et al., 2008), Cymbopogon citratus D.C. (COSTA et al., 2008), Baccharis trimera (Less.) D.C. (SILVA et al., 2007), Ocimum basilicum L. (BLANK et al., 2005). However the different responses to organic fertilizer described in those studies, both in the production of biomass and the levels and chemical composition of essential oils, demonstrate the need for individual evaluation of each plant species.

Within this context, aimed evaluate the effect of different dosages of cattle and poultry manure on biomass production and the content, yield and chemical composition of the essential oil of A. millefolium.

\section{MATERIAL AND METHODS}

Trials were carried out from February to June of 2009 in a greenhouse of the Laboratory of Tissue Culture and Medicinal, Aromatic and Spice Herbs in the Department of Agriculture (DAG) of the Federal University of Lavras (UFLA). Plants of A. millefolium L. were obtained by propagating rhizomes from mother plants of the Medicinal Garden at UFLA. After 60 days, the plants were transplanted to plastic pots, each with a capacity of $10 \mathrm{~L}$, containing soil (dark-red latosol) mixed with organic fertilizers, in two distinct trials: Trial I (cattle manure - CM) : 1) soil with no fertilizer; 2) soil $+3.0 \mathrm{~kg} \mathrm{~m}^{-2} \mathrm{CM}$; 3) soil $+6.0 \mathrm{~kg} \mathrm{~m}^{-2}$ $\mathrm{CM}$; 4) soil + $9.0 \mathrm{~kg} \mathrm{~m}^{-2} \mathrm{CM}$; 5) soil + $12.0 \mathrm{~kg}^{-2} \mathrm{CM}$; and Trial II (poultry manure - PM): 1 ) soil with no fertilizer ; 2) soil + $1.5 \mathrm{~kg} \mathrm{~m}^{-2} \mathrm{PM}$; 3 ) soil $+3.0 \mathrm{~kg} \mathrm{~m}^{-2}$ $\mathrm{PM}$; 4)soil + $4.5 \mathrm{~kg} \mathrm{~m}^{-2} \mathrm{PM}$; 5) soil + $6.0 \mathrm{~kg} \mathrm{~m}^{-2} \mathrm{PM}$. The experimental design was completely randomised with four replications and four plants per lot.

The soil and fertilizer used in the tests were analysed by the Laboratory for Soil Analysis of UFLA. The chemical characteristics of the soil were: $\mathrm{pH}$ in water $=5.6 ; \mathrm{P}$ and $\mathrm{K}\left(\mathrm{mg} \mathrm{dm}^{-3}\right)=0.6$ and $14 ; \mathrm{Ca}^{2+}$, $\mathrm{Mg}^{2+}, \mathrm{Al}^{3+}, \mathrm{H}+\mathrm{Al}\left(\mathrm{cmol}_{\mathrm{c}} \mathrm{dm}^{-3}\right)=0.5,0.1,0.0,2.1$; base saturation $\mathrm{V}(\%)=23.4$; organic matter $\left(\operatorname{dag} \mathrm{kg}^{-1}\right)=1.4$; The organic fertilizers resulted in the following values for the cattle manure $\mathrm{N}, \mathrm{P}, \mathrm{K}, \mathrm{Na}, \mathrm{Ca}, \mathrm{Mg}, \mathrm{S}\left(\mathrm{g} \mathrm{kg}^{-1}\right)$ $=18.0 ; 5.1 ; 13.0 ; 1.5 ; 4.1 ; 3.2 ; 2.6 ; \mathrm{B}, \mathrm{Cu}, \mathrm{Fe}, \mathrm{Mn}, \mathrm{Zn}$ $\left(\mathrm{mg} \mathrm{g}^{-1}\right)=5.6 ; 39.0 ; 12,848.0 ; 461.0 ; 150.0$. For the poultry manure the values were: $\mathrm{N}, \mathrm{P}, \mathrm{K}, \mathrm{Na}, \mathrm{Ca}, \mathrm{Mg}, \mathrm{S}$ $\left(\mathrm{g} \mathrm{kg}^{-1}\right)=21.0 ; 20.0 ; 7.3 ; 2.2 ; 46.0 ; 2.8 ; 3.1 ; \mathrm{B} \mathrm{Cu}, \mathrm{Fe}$, $\mathrm{Mn}, \mathrm{Zn}\left(\mathrm{mg} \mathrm{kg}^{-1}\right)=17.0 ; 74.0 ; 4,601.0 ; 315.0 ; 314.0$.

At 110 days after planting, the plants were harvested, separated into roots and shoots, and oven dried with forced air at $38 \pm 1^{\circ} \mathrm{C}$ until reaching constant weight, and weighed with an analytical balance. Plant growth was determined by the accumulation of leaf dry weight (LDW, $\mathrm{g} \mathrm{plant}^{-1}$ ), root dry weight (RDW, g plant ${ }^{-1}$ ) and the root to shoot ratio (R/S).

The essential oil of A. millefolium was extracted by hydrodistillation with a modified Clevenger apparatus, using $40 \mathrm{~g}$ of leaf dry biomass (LDW) in $500 \mathrm{~mL}$ of distilled water for 90 minutes. A completely randomised experimental design was used with four replications per treatment. The essential oil was purified by liquid-liquid partition with dichloromethane. The organic phase was collected and treated with anhydrous magnesium sulphate, filtered, and the solvent then evaporated at room temperature in a gas exhaustion chamber. The content (g $\left.100 \mathrm{~g}^{-1} \mathrm{LDW}\right)$ and yield $\left(\mathrm{g} \mathrm{plant}^{-1}\right)$ of the essential oil from the dry base of the leaves were determined.

Analysis of the chemical composition of the essential oil from the leaves of A. millefolium was carried 
out at the Laboratory for Phytochemistry, at the Department of Medicinal Plants of DAG/UFLA. A composite sample was used in these analyses, made up by combining the aliquot parts contained in equivalent weights of the essential oil from the replications of each treatment.

Quantitative analyses of the oil were conducted employing gas chromatography coupled with a hydrogen-flame ionization detector (GC-FID) using an Agilent ${ }^{\circledR} 7890$ A system equipped with a fused-silica capillary column HP-5ms $(30 \mathrm{~m}$ length $\times 025 \mathrm{~mm}$ inner diameter $\times 0.25 \mu \mathrm{m}$ film thickness) (California, USA). Helium was used as the carrier gas at a flow rate of 1.0 $\mathrm{mL} \mathrm{min}^{-1}$; the temperature of the injector and detector were kept at 220 to $240{ }^{\circ} \mathrm{C}$ respectively. The initial temperature of the oven was $60{ }^{\circ} \mathrm{C}$ with a temperature ramp of $3{ }^{\circ} \mathrm{C} \mathrm{min}{ }^{-1}$ to $150{ }^{\circ} \mathrm{C}$ followed by an isotherm of 10 minutes and then a ramp of $10{ }^{\circ} \mathrm{C} \mathrm{min}^{-1}$ to $270{ }^{\circ} \mathrm{C}$. The oil was dissolved in ethyl acetate $(1 \%, \mathrm{v} / \mathrm{v})$ and automatically injected into the chromatograph using an injection volume of $1.0 \mu \mathrm{L}$, in split mode, at an injection ratio of 1:50. The concentration of the constituents was calculated using their complete respective peak areas relative to the total area of all the constituents of the sample.

Qualitative analyses of the oil were carried out by gas chromatography-mass spectrometry (GC-MS) using an Agilent ${ }^{\circledR} 5975 \mathrm{C}$ system operated with electron impact ionization at $70 \mathrm{e} \mathrm{V}$, in scanning mode, at a speed of 1.0 scan $\mathrm{sec}^{-1}$, with a mass acquisition range of $40-400 \mathrm{~m} / \mathrm{z}$. The chromatographic conditions were the same as those employed in the quantitative analyses. The components were identified by comparing their Kovats retention indices with mass-spectra and retention-index data taken from the literature (ADAMS, 2007; KOTAN et al., 2010) and by comparison of the mass spectra with the NIST/ EPA/NIH library database (NATIONAL INSTITUTE OF STANDARDS AND TECHNOLOGY, 2008).

Data of the shoot dry weight (SDW), root dry weight (RDW), root to shoot ratio (R/S), and content and yield of the essential oil were subjected to regression analysis $(\mathrm{p}<0.05)$ using the SISVAR ${ }^{\circledR}$ statistical software (FERREIRA, 2007).

\section{RESULTS AND DISCUSSION}

Achillea millefolium plants responded positively in vegetative growth relative to the dosages and sources of manure, unlike the plants which received no fertilizer and which presented reduced size (Figure 1).

However, A. millefolium responded better to fertilization with poultry manure, showing increased SDW production at a value of $36 \mathrm{~g} \mathrm{plant}^{-1}$ and a dosage of $6 \mathrm{~kg} \mathrm{~m}^{-2}$ compared to $25 \mathrm{~g}$ plant $^{-1}$ at a dosage of $12 \mathrm{~kg} \mathrm{~m}^{-2}$ of cattle manure (Figures $2 \mathrm{~A}$ and B). The superiority of the poultry manure was $30.5 \%$ when applying half the dosage of cattle manure needed to obtain maximum SDW accumulation. Comparing the chemical analyses of the fertilizers, it can be seen that on average the poultry manure had higher nutrient levels, probably resulting in better gains in SDW. Studies by Scheffer et al. (1993) showed a positive response of $A$. millefolium to organic fertilization, confirming the results observed in the present study. Other studies, which have evaluated the increase in biomass production in medicinal and aromatic plants by the application of organic fertilizers, showed similar results (BRANT et al., 2010; CORRÊA et al., 2010; COSTA et al., 2008; ROSAL et al., 2011).

Figure 1 - Plants of Achillea millefolium L. grown in pots under different dosages of organic fertilization. A - poultry manure $\left(0.0,1.5,3.0,4.5\right.$ and $\left.6 \mathrm{~kg} \mathrm{~m}^{-2}\right)$. B - cattle manure $\left(0.0,3.0,6.0,9.0\right.$ and $\left.12.0 \mathrm{~kg} \mathrm{~m}^{-2}\right)$

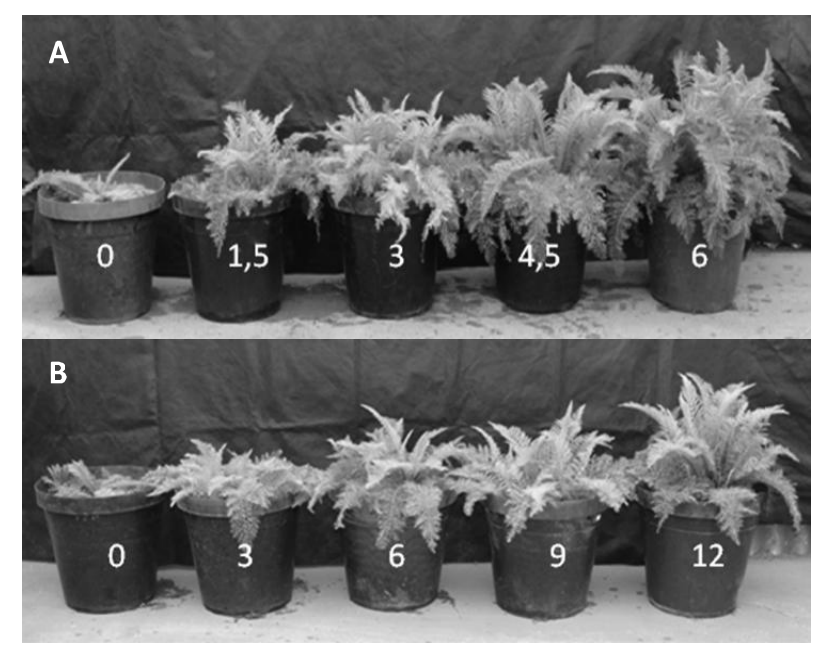

Analysing the RDW, a quadratic response was seen, where the point of maximum accumulation was $35 \mathrm{~g}$ plant $^{-1}$ at a dosage of $6 \mathrm{~kg} \mathrm{~m}^{-2}$ for poultry manure and $28 \mathrm{~g} \mathrm{plant}^{-1}$ at a dosage of $12 \mathrm{~kg} \mathrm{~m}^{-2}$ for cattle manure (Figures $2 \mathrm{C}$ and D). A quadratic tendency was seen for R/S for poultry manure, with values ranging from 0.71 to 1.12 (Figures $2 \mathrm{E}$ and $\mathrm{F}$ ). The poultry manure at a dosage of $6 \mathrm{~kg} \mathrm{~m}^{-2}$ showed a close relationship to a value of one $(\mathrm{R} / \mathrm{S}=0.96)$ (Figure 2 D). Cattle manure on the other hand, exhibited linear behaviour with values of between 0.71 and 1.30. At a dosage of $12 \mathrm{~kg} \mathrm{~m}^{-2}$, plants fertilized with cattle manure had an R/S of 1.12, indicating higher drainage to the root (Figure 2F).

The essential oil extracted from the leaves of $A$. millefolium was characterised as a high viscosity liquid oil with intense blue colouration. There was no statistical 
difference between the dosages and sources of organic fertilizers for the levels of the essential oil of A. millefolium, which were in the range of 0.05 to $0.07 \%$.

The yield of essential oil showed a significant difference between the dosages of both organic fertilizers (Figures $2 \mathrm{G}$ and $\mathrm{H}$ ). The poultry manure showed an increasing linear curve adjustment where the maximum yield was $0.025 \mathrm{~g} \mathrm{plant}^{-1}$ at a dosage of
$6 \mathrm{~kg} \mathrm{~m}^{-2}$ (Figure $2 \mathrm{G}$ ). The cattle manure also had a significant response to the applied dosages compared to the control, displaying a quadratic curve adjustment, and presenting the highest yield of oil $\left(0.01 \mathrm{~g} \mathrm{plant}^{-1}\right)$ at a dosage of $9 \mathrm{~kg} \mathrm{~m}^{-2}$ (Figure $2 \mathrm{H}$ ).

Confirming this study, Amaral et al. (2008) noted that there was an increase in the yield of essential oil of Chamomila recutita, due to the

Figure 2 - Production of shoot dry weight (A and B), root dry weight (C and D), root to shoot ratio (E and F) and essential oil yield (G and $H)$ of Achillea millefolium L. Plants, fertilized with different dosages of poultry manure (left column ) and cattle manure (right column)
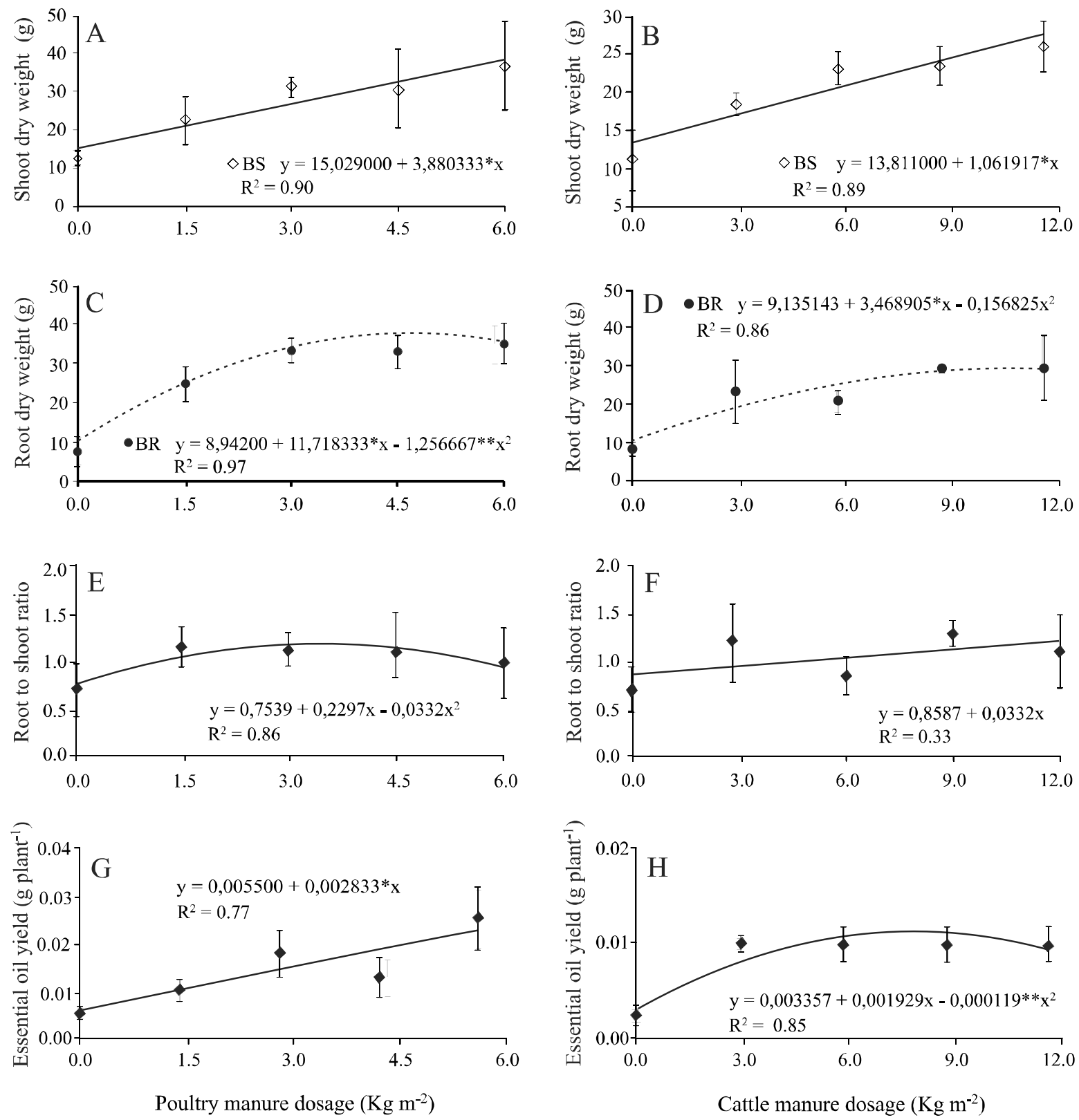

*Significant by the F-test at $5 \%$ 
increase in biomass from fertilization with nitrogen. In Ocimum selloi, Costa et al. (2008) found that plants fertilized with $4.0 \mathrm{~kg} \mathrm{~m}^{-2}$ of poultry manure had a higher yield of essential oil $\left(0.031 \mathrm{~g} \mathrm{plant}^{-1}\right)$ compared to plants fertilized with $8.1 \mathrm{~kg} \mathrm{~m}^{-2}$ of cattle manure $\left(0.023 \mathrm{~g} \mathrm{plant}^{-1}\right)$, concluding that the increase in oil may have been influenced by the increase in the levels of available nutrients in the soil.

Organic fertilization with poultry and cattle manure resulted in no marked qualitative or quantitative differences to the essential oils. Chromatographic analysis indicated a very complex chemical composition of the essential oil of $A$. millefolium, containing around 48 chemical components (Tables 1 and 2). The main constituents were borneol, spathulenol , E- nerolidol and chamazulene, which made up nearly $59 \%$ of the relative area of the chromatographic peaks.

Achillea millefolium, regardless of the amount of fertilization, presented high levels of chamazulene: in plants fertilized with poultry manure its concentrations ranged from 44.25 to $46.14 \%$, in those fertilized with cattle manure, from 40.49 to $52.01 \%$. For levels of the constituents, borneol (3.13 to 5.45\%), spathulenol (4.48 to $6.29 \%$ ), $e$-nerolidol (3.94 to $5.23 \%$ ) and $\beta$-cubebene (0.83 to $4.03 \%)$, the differences were less significant. Phytochemical studies carried out in various regions of the world have also shown the high complexity and diversity of the volatile chemical composition of $A$. millefolium (GUDAITYTE; VENSKUTONIS, 2007; JUDZENTIENE; MOCKUTE, 2010).

Table 1 - Chemical composition of the essential oil of Achillea millefolium cultivated with different dosages of poultry manure

\begin{tabular}{|c|c|c|c|c|c|c|}
\hline \multirow{2}{*}{ Constituents } & \multirow{2}{*}{$\mathrm{IR}^{*}$} & \multicolumn{5}{|c|}{ Poultry manure $\left(\mathrm{kg} \mathrm{m}^{-2)}\right.$} \\
\hline & & 0 & 1.5 & 3 & 4.5 & 6 \\
\hline$\gamma$-terpinene & 1059 & 0.12 & 0.09 & nd & 0.07 & 0.11 \\
\hline terpinolene & 1087 & 0.31 & 0.24 & 0.31 & 0.22 & 0.32 \\
\hline borneol & 1152 & 4.13 & 3.31 & 5.16 & 3.13 & 4.46 \\
\hline cis-dihydro- $\alpha$-terpineol & 1164 & 0.48 & 0.36 & 0.64 & 0.39 & 0.71 \\
\hline terpinen-4-ol & 1178 & 1.2 & 1.19 & 1.81 & 1.12 & 1.54 \\
\hline bornyl acetate & 1274 & 0.15 & 0.17 & 0.2 & 0.14 & 0.2 \\
\hline thymol acetate & 1347 & nd & 0.23 & 0.26 & 0.22 & 0.24 \\
\hline Z-caryophyllene & 1409 & 1.41 & 2.46 & 2.4 & 1.94 & 2.28 \\
\hline humulene & 1442 & 0.27 & 0.48 & 0.45 & 0.4 & 0.44 \\
\hline$\beta$-cubebene & 1470 & 1.34 & 0.83 & 1.56 & 1.97 & 4.03 \\
\hline$\beta$-ionone & 1476 & 0.25 & 0.2 & 0.28 & 0.26 & 0.31 \\
\hline germacrene D & 1485 & nd & nd & nd & 0.23 & 0.31 \\
\hline$\alpha$-farnesene & 1498 & 0.18 & 0.2 & 0.39 & 0.51 & 0.81 \\
\hline cubebol & 1513 & nd & 0.17 & nd & 0.13 & 0.18 \\
\hline$\delta$-cadinene & 1524 & nd & 0.21 & 0.4 & 0.39 & 0.36 \\
\hline cis-nerolidol & 1540 & 0.79 & 0.56 & 0.84 & 0.91 & 0.9 \\
\hline$\alpha$-calacorene & 1543 & nd & nd & 0.29 & 0.32 & 0.27 \\
\hline aromadendrene oxide & 1550 & 2.32 & 3.02 & 3.61 & 3.44 & 3.19 \\
\hline spathulenol & 1561 & 5.47 & 4.82 & 5.5 & 5.47 & 4.95 \\
\hline$E$-nerolidol & 1566 & 4.37 & 5.23 & 5.05 & 4.73 & 4.25 \\
\hline caryophyllene alcohol & 1571 & 0.48 & 0.39 & 0.35 & 0.37 & 0.35 \\
\hline sesquisabinene hydrate & 1574 & 0.47 & 0.28 & 0.24 & 0.16 & 0.22 \\
\hline caryophyllene oxide & 1576 & 1.4 & 1.65 & 1.62 & 1.7 & 1.55 \\
\hline globulol & 1588 & 0.29 & 0.2 & nd & 0.16 & 0.25 \\
\hline$\beta$-copaen-4-ol & 1590 & 0.85 & 1.23 & 1.07 & 1.17 & 0.92 \\
\hline
\end{tabular}


Continuação Tabela 1

\begin{tabular}{|c|c|c|c|c|c|c|}
\hline viridiflorol & 1594 & 1.4 & 0.85 & 0.77 & 0.8 & 1.46 \\
\hline ledol & 1604 & 0.17 & 0.38 & 0.31 & 0.37 & 0.25 \\
\hline humulene epoxide & 1606 & nd & 0.27 & nd & 0.21 & 0.22 \\
\hline$\beta$-himachalene oxide & 1618 & nd & 0.26 & nd & 0.13 & nd \\
\hline 10-epi- $\gamma$-eudesmol & 1625 & 1.08 & 0.89 & 0.82 & 0.9 & 0.76 \\
\hline 1-epi-cubenol & 1630 & 0.87 & 0.58 & 0.57 & 0.73 & 0.7 \\
\hline$\alpha / \beta$-caryophyla-4(14),8(15)-dien-5-ol & 1637 & 2.87 & 1.76 & 1.72 & 2.05 & 2.19 \\
\hline t-muurolol & 1639 & 0.36 & 0.51 & 0.4 & 0.52 & 0.39 \\
\hline$\alpha$-bisabolol oxide $B$ & 1648 & 0.42 & 0.43 & 0.31 & 0.39 & 0.4 \\
\hline$\beta$-eudesmol & 1652 & nd & 0.29 & 0.23 & 0.41 & 0.26 \\
\hline selin-11-en-4- $\alpha$-ol & 1657 & 0.44 & 0.46 & nd & 0.4 & nd \\
\hline 14-hydroxy-9-epi- $\beta$ - caryophyllene & 1668 & nd & 0.78 & 0.68 & 0.89 & nd \\
\hline$\alpha$-cadinol & 1676 & 2.46 & 1.48 & 1.25 & 1.49 & 1.69 \\
\hline$\alpha$-bisabolol & 1683 & 1.09 & 0.99 & 1.02 & 1.07 & 0.97 \\
\hline 2Z,6Z-farnesol & 1701 & 1.07 & 1.27 & 1 & 1.26 & 0.94 \\
\hline chamazulene & 1734 & 45.4 & 44.25 & 46.14 & 42.67 & 43.38 \\
\hline $2 E, 6 E$-farnesol & 1741 & 0.35 & 0.28 & nd & 0.24 & nd \\
\hline$\alpha$-bisabolol oxide $\mathrm{A}$ & 1744 & nd & 0.26 & nd & 0.28 & nd \\
\hline 14-hydroxy- $\alpha$-muurolene & 1779 & 2.03 & 1.48 & 1.74 & 2.16 & 1.73 \\
\hline$\beta$-eudesmol acetate & 1791 & 2.68 & 2.77 & 2.95 & 3.46 & 2.65 \\
\hline epi- $\alpha$-bisabolol acetate & 1800 & 2.18 & 1.67 & 1.74 & 1.88 & 1.59 \\
\hline isolongifolol oxide & 1816 & 0.73 & 0.54 & 0.61 & 0.78 & 0.61 \\
\hline $2 E, 6 E$-farnesyl acetate & 1849 & 0.65 & 0.46 & 0.48 & 0.65 & 0.51 \\
\hline Total monoterpenes & 7.8 & 8.05 & 10.78 & 7.23 & 8.75 & \\
\hline Total sesquiterpenes & 84.7 & 82.38 & 84.39 & 86.06 & 84.3 & \\
\hline Total & 92.5 & 90.43 & 95.17 & 93.29 & 93.04 & \\
\hline
\end{tabular}

*Retention index relative to the n-alkanes (C8-C20) series in a HP-5MS column. nd: not detected

Table 2 - Chemical composition of the essential oil of Achillea millefolium cultivated with different dosages of cattle manure

\begin{tabular}{lcccccc}
\hline \multirow{2}{*}{ Constituents } & IR* & \multicolumn{5}{c}{ Cattle manure $\left(\mathrm{kg} \mathrm{m}^{-2}\right)$} \\
\cline { 3 - 7 } & & 0 & 3 & 6 & 9 & 12 \\
\hline$\gamma$-terpinene & 1059 & 0.12 & 0.20 & 0.11 & 0.18 & 0.22 \\
terpinolene & 1087 & 0.31 & 0.43 & 0.29 & 0.38 & 0.37 \\
borneol & 1152 & 4.13 & 5.45 & 3.88 & 4.56 & 4.32 \\
cis-dihydro- $\alpha$-terpineol & 1164 & 0.48 & 0.77 & 0.40 & 0.57 & 0.58 \\
terpinen-4-ol & 1178 & 1.20 & 1.66 & 1.18 & 1.40 & 1.36 \\
bornyl acetate & 1274 & 0.15 & 0.23 & 0.15 & 0.17 & 0.19 \\
thymol acetate & 1347 & nd & 0.24 & 0.17 & 0.16 & 0.21 \\
$Z$-caryophyllene & 1409 & 1.41 & 1.99 & 1.70 & 1.83 & 2.18 \\
humulene & 1442 & 0.27 & 0.37 & 0.33 & 0.35 & 0.41 \\
\hline
\end{tabular}


Continuação Tabela 2

\begin{tabular}{|c|c|c|c|c|c|c|}
\hline$\beta$-cubebene & 1470 & 1.34 & 2.26 & 1.80 & 2.33 & 2.18 \\
\hline$\beta$-ionone & 1476 & 0.25 & 0.27 & 0.24 & 0.29 & 0.25 \\
\hline germacrene D & 1485 & nd & 0.17 & nd & nd & nd \\
\hline$\alpha$-farnesene & 1498 & 0.18 & 0.32 & 0.30 & 0.41 & 0.49 \\
\hline cubebol & 1513 & nd & 0.20 & 0.30 & nd & nd \\
\hline$\delta$-cadinene & 1524 & nd & 0.20 & 0.29 & nd & 0.22 \\
\hline cis-nerolidol & 1540 & 0.79 & 0.89 & 1.05 & 0.68 & 0.49 \\
\hline$\alpha$-calacorene & 1543 & nd & 0.12 & 0.18 & nd & nd \\
\hline aromadendrene oxide & 1550 & 2.32 & 3.05 & 3.37 & 2.62 & 2.65 \\
\hline spathulenol & 1561 & 5.47 & 5.38 & 6.29 & 5.13 & 4.48 \\
\hline$E$-nerolidol & 1566 & 4.37 & 4.83 & 4.87 & 4.21 & 3.94 \\
\hline caryophyllene alcohol & 1571 & 0.48 & 0.44 & 0.47 & 0.33 & 0.28 \\
\hline sesquisabinene hydrate & 1574 & 0.47 & 0.42 & 0.41 & 0.30 & 0.20 \\
\hline caryophyllene oxide & 1576 & 1.40 & 1.58 & 1.60 & 1.45 & 1.34 \\
\hline globulol & 1588 & 0.29 & 0.34 & 0.38 & 0.20 & nd \\
\hline$\beta$-copaen-4-ol & 1590 & 0.85 & 0.96 & 1.00 & 0.86 & 0.83 \\
\hline viridiflorol & 1594 & 1.40 & 1.62 & 1.67 & 1.17 & 0.79 \\
\hline ledol & 1604 & 0.17 & 0.32 & 0.31 & 0.25 & 0.21 \\
\hline humulene epoxide & 1606 & nd & 0.27 & nd & 0.21 & 0.22 \\
\hline$\beta$-himachalene oxide & 1618 & nd & 0.19 & 0.16 & nd & nd \\
\hline 10-epi- $\gamma$-eudesmol & 1625 & 1.08 & 1.01 & 1.11 & 0.91 & 0.71 \\
\hline 1-epi-cubenol & 1630 & 0.87 & 0.81 & 0.92 & 0.74 & 0.52 \\
\hline$\alpha / \beta$-caryophyll-4(14),8(15)-dien-5-ol & 1637 & 2.87 & 2.37 & 2.74 & 2.18 & 1.66 \\
\hline t-muurolol & 1639 & 0.36 & 0.38 & 0.33 & 0.34 & 0.33 \\
\hline$\alpha$-bisabolol B oxide & 1648 & 0.42 & 0.44 & 0.40 & 0.39 & 0.32 \\
\hline$\beta$-eudesmol & 1652 & nd & 0.25 & 0.20 & nd & nd \\
\hline selim-11-en-4- $\alpha$-ol & 1657 & 0.44 & 0.41 & nd & nd & nd \\
\hline 14-hydroxy-9-epi- $\beta$ - caryophyllene & 1668 & 2.16 & 1.20 & 0.70 & 2.07 & 0.98 \\
\hline$\alpha$-cadinol & 1676 & 2.46 & 1.87 & 2.16 & 1.96 & 1.47 \\
\hline$\alpha$-bisabolol & 1683 & 1.09 & 0.92 & 1.00 & 1.06 & 1.03 \\
\hline 2Z,6Z-farnesol & 1701 & 1.07 & 0.93 & 1.19 & 1.03 & 1.12 \\
\hline chamazulene & 1734 & 45.35 & 40.49 & 42.48 & 47.27 & 52.01 \\
\hline $2 E, 6 E$-farnesol & 1741 & 0.35 & 0.23 & 0.30 & nd & 0.30 \\
\hline 14-hydroxy- $\alpha$-muurolene & 1779 & 2.03 & 1.46 & 2.14 & 1.87 & 1.61 \\
\hline$\beta$-eudesmol acetate & 1791 & 2.68 & 2.13 & 2.14 & 2.90 & 2.60 \\
\hline epi- $\alpha$-bisabolol acetate & 1800 & 2.18 & 1.39 & 1.79 & 1.84 & 1.76 \\
\hline isolongifolol oxide & 1816 & 0.73 & 0.49 & 0.71 & 0.66 & 0.58 \\
\hline $2 E, 6 E$-farnesyl acetate & 1849 & 0.65 & 0.43 & 0.62 & 0.60 & 0.47 \\
\hline Total monoterpenes & & 6.38 & 8.96 & 6.19 & 7.43 & 7.25 \\
\hline Total sesquiterpenes & & 88.24 & 83.42 & 87.66 & 88.39 & 88.65 \\
\hline Total & & 94.62 & 92.38 & 93.84 & 95.82 & 95.90 \\
\hline
\end{tabular}

*Retention index relative to the n-alkanes (C8-C20) series in a HP-5MS column. nd: not detected 


\section{CONCLUSIONS}

1. For the accumulation of dry biomass, and thus a higher yield of essential oil, Achillea millefolium is a medicinal plant which needs organic manure. However, fertilization with cattle manure $\left(0\right.$ to $\left.12.0 \mathrm{~kg}-\mathrm{m}^{2}\right)$ or poultry manure ( 0 to $\left.6.0 \mathrm{~kg} \mathrm{~m}^{-2}\right)$ does not significantly affect either the composition or concentration of the chemical constituents of the oil;

2. Fertilization with poultry manure at a dosage of $6 \mathrm{~kg} \mathrm{~m}^{-2}$ produced a greater accumulation of shoot biomass and greater yield of essential oil. However the chamazulene content is higher in plants fertilized with $12 \mathrm{~kg} \mathrm{~m}^{-2}$ of cattle manure.

\section{ACKNOWLEDGEMENTS}

The authors wish to thank the Foundation for Research Support of the State of Minas Gerais (FAPEMIG), the National Council for Scientific and Technological Development $(\mathrm{CNPq})$ and the Coordination for the Improvement of Higher Education Personnel (CAPES) for their financial support of this project and for the student and productivity grants awarded.

\section{REFERENCES}

ADAMS, R. P. Identification of essential oil components by gas chromatography/mass spectrometry. Illinois: Allured, 2007. 804 p.

AMARAL, W. et al. Desenvolvimento, rendimento e composição de óleo essencial de camomila [Chamomila recutita (L.) Rauschert] sob adubação orgânica e mineral. Revista Brasileira Plantas Medicinais, v. 10, n. 4, p. 1-8, 2008.

BENEDEK, B.; KOPP, B. Achillea millefolium L. s.1. revisited: recent findings confirm the traditional use. Wiener Medizinische Wochenschrift, v. 157, n. 13, p. 312-314, 2007.

BENEDEK, B.; KOPP, B.; MELZIG, M. F. Achillea millefolium L. s.1. - is the anti-inflammatory activity mediated by protease inhibition?. Journal of Ethnopharmacology, v. 113, n. 2, p. 312-317, 2007.

BIASI, L. A. et al. Adubação orgânica na produção, rendimento e composição do óleo essencial da alfavaca quimiotipo eugenol. Horticultura Brasileira, v. 27, n. 1, p. 35-39, 2009.

BLANK, A. F. et al. Influência da adubação orgânica e mineral no cultivo de manjericão cv. Genovese. Revista Ciência Agronômica, v. 36, n. 2, p. 175-180, 2005.

BRANT, R. S. et al. Produção de biomassa e teor do óleo essencial de cidrão em função da adubação orgânica. Horticultura Brasileira, v. 28, n. 5, p. 111-114, 2010.
BRASIL. Ministério da Saúde. Publica a Relação Nacional de Plantas Medicinais de Interesse ao SUS. 2009. Disponível em: <http://189.28.128.100/portal/saude/profissional/vi>. Acesso em: 09 maio 2011.

CORRÊA, R. M. et al. Adubação orgânica na produção de biomassa de plantas, teor e qualidade de óleo essencial de orégano (Origanum vulgare L.) em cultivo protegido. Revista Brasileira de Plantas Medicinais, v. 12, n. 1, p. 80-89, 2010.

COSTA, L. C. B. et al. Efeito da adubação química e orgânica na produção de biomassa e óleo essencial em capim-limão [Cymbopogon citratus (DC.) Stapf.]. Revista Brasileira de Plantas Medicinais, v. 10, n. 1, p. 16-20, 2008.

FERREIRA, D. F. SISVAR 5.0: sistema de análise estatística. Lavras: UFLA/DEX, 2007.

GUDAITYTE, O.; VENSKUTONIS, P. R. Chemotypes of Achillea millefolium transferred from 14 different locations in Lithuania to the controlled environment. Biochemical Systematics and Ecology, v. 35, n. 9, p. 582-592, 2007.

JUDZENTIENE, A.; MOCKUTE, D. Essential oil composition of two yarrow taxonomic forms. Central European Journal of Biology, v. 5, n. 3, p. 346-352, 2010.

KAPLAN, M. et al, The effects of different organic manure applications on the dry weight and the essential oil quantity of sage (Salvia fruticosa Mill.). Acta Horticulturae, v. 826, n. 1, p. 147-151, 2009.

KOTAN, A. C. et al. Antibacterial activities of essential oils and extracts of Turkish Achillea, Satureja and Thymus species against plant pathogenic bacteria. Journal of the Science of Food Agriculture, v. 90, n. 1, p. 145-160, 2010.

LORENZI, H.; MATOS, F. J. A. Plantas medicinais no Brasil: nativas e exóticas cultivadas. São Paulo: Instituto Plantarum, 2002. p. 129-130.

NATIONAL INSTITUTE OF STANDARDS AND TECHNOLOGY. PC version 2.0 of the NIST/EPA/NIH mass spectral library. Gaithersburg, 2008.

ROSAL, L. F. et al. Produção vegetal e óleo essencial de boldo pequeno em função de fontes de adubos orgânicos. Revista Ceres, v. 58, n. 5, p. 670-678, 2011.

SANTOS, M. F. et al. Esterco bovino e biofertilizante no cultivo de erva-cidreira-verdadeira (Melissa officinalis L.). Revista Brasileira de Plantas Medicinais, v. 11, n. 4, p. 355359, 2009.

SCHEFFER, M. C. et al. Influence of organic fertilization on the biomass, yield and composition of the essential oil of Achillea millefolium L. Acta Horticulturae, v. 331, n. 14, p. 109-112, 1993.

SCHIPPMANN, U. et al. Impact of cultivation and gathering of medicinal plants on biodiversity: global trends and issues. 2002. Disponível em: <www.guildedesherboristes.org/ wpcontent/uploads/2010/07/Schippmann-et-al.-2002-Impactof-cultivation-and-gathering-med-plants-on-biodiversity. pdf>. Acesso em: 09 mar. 2012. 
SILVA, F. G. et al. Influence of manure and fertilizer on Baccharis trimera (Less.) D.C. growth and essential oil yield. Journal of Herbs, Spices and Medicinal Plants, v. 13, n. 1, p. 83-92, 2007.
SURRAGE, V. A. et al. Benefits of vermicompost as a constituent of growing substrates used in the production of organic greenhouse tomatoes. HortScience, v. 45, n. 10, p. 1510-1515, 2010 . 